\title{
Zwolnienia z przyczyn niedotyczących pracowników wobec pandemii COVID-19
}

\section{Dismissals for Employee-Unrelated Reasons during the COVID-19 Pandemic}

\author{
Summary
}

The purpose of this article is to evaluate the anti-crisis regulations from the perspective of the level of the safeguarding of employees' interests. The authors discuss the instruments of employer support and of labor market in the context of the pandemic crisis and the resulting layoffs. They pay special attention to the situation of administration officials (civil servants) because of the specific solutions adopted regarding this group. The authors also share their reflections on the changing practice in collective labor relations and on the changes in the functioning of the participants in the employment relationship.

Keywords: layoffs, COVID-19, reasons not related to the employee

\section{Uwagi wstępne}

Pandemia COVID-19 ma poważny wpływ na sytuację gospodarczą i funkcjonowanie rynku pracy. W wielu państwach nastąpił gwałtowny spadek PKB (globalnie o 4,4\%). W odniesieniu do sfery zatrudnienia szacowano, że w 2020 r. liczba godzin pracy uległa zmniejszeniu o około 8,8\%, co odpowiada około 255 milionom miejsc pracy. Musiało to prowadzić do zwolnień, zmniejszenia się odsetka osób aktywnych 
zawodowo oraz wzrostu poziomu bezrobocia (w sumie o 1,1\%, przy dość znacznym zróżnicowaniu regionalnym) ${ }^{1}$. W Polsce dotychczasowy przebieg kryzysu z perspektywy rynku pracy był stosunkowo łagodny. Spadek PKB jest mniejszy niż w większości państw europejskich. Wzrost poziomu bezrobocia był odczuwalny, ale jeszcze nie alarmujący ${ }^{2}$ W jakimś zakresie sytuację mogły stabilizować mechanizmy wprowadzane $w$ tzw. tarczach: antykryzysowej ${ }^{3}$ oraz finansowej ${ }^{4}$ (choć ustalenie rzeczywistej efektywności tych mechanizmów wymagałoby przeprowadzenia odrębnych badań). Podobnie jak $\mathrm{w}$ innych systemach prawnych ${ }^{5}$, polski ustawodawca starał się ograniczać możliwość zwolnień, w szczególności wiążąc pomoc publiczną ze stabilizacją zatrudnienia.

Pomimo dość stabilnej sytuacji gospodarczej oraz podejmowanych działań osłonowych część pracodawców, których sytuacja finansowa uległa pogorszeniu lub którzy musieli ograniczyć lub wręcz wstrzymać działalność (co miało miejsce w niektórych sektorach gospodarki),

1 Zob. ILO Monitor, COVID-19 and the world of work. Seventh edition, 21 January 2021, https://www.ilo.org/wcmsp5/groups/public/---dgreports/---dcomm/documents/ briefingnote/wcms_767028.pdf, s. 1-12, choć jednocześnie dostrzega się, że w trzecim i czwartym kwartale roku nastąpiła poprawa sytuacji. Do regionów najbardziej dotkniętych wzrostem bezrobocia należy Europa Południowa. W mniejszym stopniu zjawisko to wystąpiło w pozostałych częściach kontynentu.

${ }_{2}$ Od początku pandemii poziom bezrobocia nieznacznie zwiększał się. Według danych Ministerstwa Rozwoju, Pracy i Technologii stopa bezrobocia rejestrowanego w grudniu 2020 r. wyniosła 6,2\% (https://www.gov.pl/web/rozwoj-praca-technologia/ szacunek-mrpit-62-wyniosla-stopa-bezrobocia-rejestrowanego-w-grudniu-2020-r). Oznacza to wzrost o 1 p.p. w stosunku do grudnia 2019 r.

${ }^{3}$ Ustawa z dnia 2 marca 2020 r. o szczególnych rozwiązaniach związanych z zapobieganiem, przeciwdziałaniem i zwalczaniem COVID-19, innych chorób zakaźnych oraz wywołanych nimi sytuacji kryzysowych, Dz.U. z 2020 r., poz. 1842 (dalej: u.z.p.z.). W pewnym zakresie ustawa odsyła do ustawy z dnia 11 października 2013 r. o szczególnych rozwiązaniach związanych z ochroną miejsc pracy, Dz.U. z 2019 r., poz. 669 ze zm.

${ }^{4}$ Ustawa z dnia 16 kwietnia 2020 r. o szczególnych instrumentach wsparcia w związku z rozprzestrzenianiem się wirusa SARS-CoV-2, Dz.U. z 2020 r., poz. 695, z późn. zm.

${ }^{5}$ W niektórych systemach prawnych ograniczano możliwość zwalniania pracowników z określonych przyczyn, w tym zwłaszcza z przyczyn ekonomicznych. Zob. m.in. A. Perulli: Regards comparés sur le droit social à l'épreuve du covid-19. „Revue de Droit du Travail" 2020, nr 4, s. 277. Artykuł 2 hiszp. dekretu królewskiego 9/2020 z dnia 27 marca 2020 r. wyraźnie stanowił, że przewidziane w przepisach antykryzysowych zawieszenie stosunku pracy lub zmniejszenie liczby godzin pracy nie uzasadnia zwolnień pracowników. 
stanęła przed koniecznością redukcji zatrudnienia. Konsekwencją są zwolnienia z przyczyn niedotyczących pracowników, w niektórych przypadkach przekraczające progi zwolnień grupowych ${ }^{6}$. Według danych z wojewódzkich urzędów pracy w okresie od marca do sierpnia 2020 r. zwolnienia grupowe objęły 15170 pracowników ${ }^{7}$. Dane z kolejnych miesięcy, oparte m.in. na informacjach przekazywanych przez pracodawców powiatowym urzędom pracy, potwierdzają zwiększenie liczby planowanych zwolnień $\mathrm{w}$ zestawieniu $\mathrm{z}$ analogicznymi miesiącami w poprzednich latach (choć, oczywiście, nie oznacza to jeszcze, że zwolnienia $\mathrm{w}$ takim zakresie faktycznie zostaną przeprowadzone). Niestety, kolejne fale pandemii wobec niezakończonego procesu szczepień mogą spowodować dalsze ograniczenia w funkcjonowaniu społeczeństwa i gospodarki, a w rezultacie dalsze pogorszenie sytuacji pracodawców. Wobec nieuzyskania lub zakończenia poszczególnych form pomocy mogą oni stanąć przed koniecznością redukcji zatrudnienia, a nawet zakończenia działalności ${ }^{8}$.

Artykuł ma dwa podstawowe cele. Po pierwsze, uporządkowaną prezentację przepisów regulujących zwolnienia z przyczyn niedotyczących pracowników w okresie pandemii. Oznacza to konieczność zestawienia dotychczasowych przepisów powszechnego prawa pracy (k.p., u.z.g.) oraz ustawodawstwa incydentalnego (tzw. tarcze antykryzysowe i finansowe) oraz określenia relacji między nimi. W tym kontekście pojawia się pytanie o praktyczną adaptację przepisów po-

${ }^{6}$ Zob. art. 1 ust. 1 ustawy z dnia 13 marca 2003 r. o szczególnych zasadach rozwiązywania z pracownikami stosunków pracy z przyczyn niedotyczących pracowników (Dz. U. z 2018 r., poz. 1969), dalej jako u.z.g.

7 K. Duda: Sytuacja na rynku pracy $w$ dobie pandemii koronawirusa. Raport. Wydział Polityki Społecznej, Rynku Pracy, Ubezpieczeń i Zdrowia OPZZ, 2020, s. 10. Z danych wojewódzkich urzędów pracy wynika, że we wrześniu 2020 r. zgłoszeniami zwolnień grupowych zostało objętych 3582 pracowników, a w październiku 2020 - 6670 pracowników, zob. G. Kowalczyк: Wrzesień był najlepszy, ale trudno o dalsza poprawę. Nowa odstona pandemii uderzy w rynek. „Dziennik Gazeta Prawna” 15.10.2020; G. KowalczyK: Rynek pracy trzyma się nieźle. „Dziennik Gazeta Prawna” 23.11.2020.

${ }^{8} \mathrm{Na}$ temat perspektyw dla rynku pracy zob. m.in. ILO Monitor, COVID-19 and the world of work. Seventh edition, 21 January 2021, https://www.ilo.org/wcmsp5/gro ups/public/---dgreports/---dcomm/documents/briefingnote/wcms_767028.pdf, s. 11 i n. Również w stosunku do polskiego rynku pracy oczekuje się niewielkiego, ale jednak, wzrostu poziomu bezrobocia. Szczególnie niepokojąca jest sytuacja pracodawców w tych branżach, które w ogóle nie mogą funkcjonować lub których funkcjonowanie jest znacznie utrudnione (gastronomia, hotelarstwo, sport amatorski). 
wszechnego prawa pracy do specyficznych warunków kryzysu pandemicznego. Drugim zadaniem jest próba oceny przyjętych rozwiązań antykryzysowych z perspektywy celów ustawodawcy (ochrona miejsc pracy) oraz spójności systemu prawnego. Podstawową metodą badawczą będzie metoda dogmatyczno-prawna. Ze względu na problemy legislacyjne, towarzyszące tworzeniu ustaw antykryzysowych (tempo prac, niespójności i wątpliwości interpretacyjne), konieczne wydaje się natomiast pewne wzmocnienie analizy celowościowej (uzasadnienia poszczególnych ustaw, ogólne założenia polityki antykryzysowej) kosztem analizy językowo-logicznej.

\section{Mechanizmy wsparcia pracodawców}

Pośredni wpływ na trwałość stosunków pracy mają różnego rodzaju mechanizmy wsparcia pracodawców. Założeniem regulacji antykryzysowych było niedopuszczenie do upadłości i likwidacji oraz masowych zwolnień grupowych. Pomoc uwzględniała całokształt sytuacji pracodawcy (np. mechanizmy przewidziane w tzw. tarczy finansowej) lub była w jakiś sposób powiązana ze sferą zatrudnienia, umożliwiając obniżenie kosztów pracy poprzez ułatwienie pracodawcom pogorszenia warunków zatrudnienia pracowników w połączeniu z uzyskaniem pomocy finansowej państwa9. Ustawodawca dawał pierwszeństwo samemu zatrudnieniu przed ochrona, rozumianą jako stabilizacja warunków zatrudnienia. Takie działania, jakkolwiek powodujące pogorszenie (przynajmniej $\mathrm{w}$ niektórych przypadkach - czasowe) warunków pracy i płacy, miało pozwolić na utrzymanie miejsc pracy - celu, który wpisuje się w szeroko rozumianą ochronę pracownika i który może być chyba uznany za wyraz proaktywnej (promocyjnej) funkcji prawa pracy ${ }^{10}$. Wśród działań bezpośrednio powiązanych ze sferą zatrudnienia ważną rolę odgrywały instytucje przestoju ekonomicznego i obniżenia wymiaru czasu (art. $15 \mathrm{~g}$ u.z.p.z.) ${ }^{11}$, a także dofi-

9 Zob. I. FlorczaK: COVID-19 and Labour Law: Poland. "Italian. Labour Law e-Journal" 2020, vol. 13, nr 1.

10 Zob. szerzej M. Sка̨рякі: Ochronna funkcja prawa pracy w gospodarce rynkowej. Kraków 2006, s. 139 i n.

${ }^{11}$ Obniżenie wymiaru czasu pracy było dopuszczalne maksymalnie o $20 \%$ wymiaru umówionego przez strony i nie więcej niż do połowy pełnego wymiaru czasu pracy. 
nansowania wynagrodzeń - powiązanego lub niezależnego od objęcia pracowników przestojem (art. $81 \S 2$ k.p.), przestojem ekonomicznym lub obniżeniem czasu pracy (art. 15g oraz 15gg u.z.p.z.), wreszcie możliwość pogorszenia warunków zatrudnienia $\mathrm{w}$ drodze porozumienia z przedstawicielami pracowników (art. 15zf ust. 1 u.z.p.z.) ${ }^{12}$. Mając na względzie wyjątkowy charakter tych rozwiązań, ustawodawca wiązał ich zastosowanie $\mathrm{z}$ wystąpieniem poważnych zakłóceń $\mathrm{w}$ funkcjonowaniu pracodawcy, których przejawem był w szczególności spadek obrotów (np. art. 15g u.z.p.z.) lub spadek przychodów ze sprzedaży towarów lub usług (art. 15gb u.z.p.z.). Inną formę wsparcia stanowiło dofinansowanie części wynagrodzeń oraz należnych od nich składek na ubezpieczenia społeczne przyznawane przez starostów (art. 15zzb u.z.p.z.), z którego mogli korzystać mikroprzedsiębiorcy oraz mali i średni przedsiębiorcy dotknięci spadkiem dochodów w następstwie COVID-1913. Co warto podkreślić, dofinansowanie nawet wówczas, gdy było powiązane z przestojem ekonomicznym lub obniżeniem wymiaru czasu pracy, nie stanowiło rekompensaty utraconych zarobków pracownika, ale swoistą refundację kosztów wynagrodzeń ponoszonych przez pracodawcę.

Ocena różnych form wsparcia pracodawców nie jest oczywista. Niemniej jednak mogły one odegrać pewną rolę w stabilizacji zatrudnienia, choć udział pracowników w ponoszeniu skutków kryzysu wy-

Mogło łączyć się z proporcjonalnym obniżeniem wynagrodzenia pracownika. W przypadku przestoju ekonomicznego, wynagrodzenie nie mogło być niższe niż 50\% wynagrodzenia pracownika sprzed przestoju. W obu przypadkach konieczne było natomiast zapewnienie pracownikowi co najmniej minimalnego wynagrodzenia za pracę, przy uwzględnieniu wymiaru czasu pracy pracownika. Gdy pracownikowi obniżono wymiar czasu pracy, dofinansowanie określono na połowę obniżonego wynagrodzenia, nie więcej jednak niż 40\% przeciętnego wynagrodzenia z kwartału poprzedzającego złożenie wniosku ogłaszanego przez GUS. Na pracownika objętego przestojem ekonomicznym dofinansowanie wynosiło połowę minimalnego wynagrodzenia za pracę, z uwzględnieniem wymiaru czasu pracy pracownika. W obu sytuacjach dofinansowanie obejmowało także wartość składek na ubezpieczenia społeczne należnych od kwot dofinansowania.

${ }^{12}$ Na temat tych rozwiązań zob. m.in. M. Latos-Mıєкоwsкa: Porozumienia zbiorowe $w$ tarczy antykryzysowej. „Praca i Zabezpieczenie Społeczne” 2020, nr 10, s. 26 i n. oraz M. Raсzкоwsкi, M. Ducki: Porozumienia zawieszajace w ustawie antykryzysowej. „Praca i Zabezpieczenie Społeczne" 2020, nr 5, s. 23-24.

${ }^{13}$ Było ono uzależnione od zakresu, w jakim nastąpił spadek obrotów, i stanowiło określoną część wynagrodzenia pracownika (jednak nie więcej niż określona część minimalnego wynagrodzenia za pracę). 
daje się nadmierny (co można ocenić jako zachwianie proporcji między ochroną miejsc pracy a ich jakością). Zakończenie (wyczerpanie) lub ograniczenie różnych form pomocy przewidzianych $\mathrm{w}$ tarczach antykryzysowych - nawet jeśli ocenianych jako niedoskonałe - może być jednym z czynników powodujących wzrost liczby zwolnień. Podstawowe pytanie dotyczy tego, czy ustawodawca ma pomysł, jak efektywnie wspierać pracodawców w kolejnych fazach pandemii i czy państwo dysponuje środkami, aby pomoc tę sfinansować?

\section{Gwarancje zatrudnienia}

Ochronę miejsc pracy, pośrednio będącą efektem różnych form wsparcia udzielanych pracodawcom, w największym stopniu realizowano w tych przypadkach, gdy pomoc publiczna została formalnie powiązana $\mathrm{z}$ ograniczeniami prawa pracodawcy do wypowiedzenia lub rozwiązania umowy o pracę (bezpośrednia realizacja proaktywnej funkcji prawa pracy). Taki mechanizm zastosowano $\mathrm{w}$ związku z korzystaniem z niektórych świadczeń z FGŚP (świadczenia na rzecz ochrony miejsc pracy) oraz wybranych form pomocy udzielanych przez starostów.

Pracodawca, który uzyskał z FGŚP dofinansowanie wynagrodzeń pracowników, nie może, w okresie pobierania tych świadczeń, wypowiadać umów o pracę z przyczyn niedotyczących pracowników (art. 15gg ust. 8). Sformułowanie "nie może” należy rozumieć jako zakaz wypowiedzenia umowy ${ }^{14}$. Szczególny charakter tego zakazu polega na tym, że został on ograniczony jedynie do przyczyn niedotyczących pracownika. Takimi przyczynami mogą być wszelkie czynniki - poza statusem pracownika i sposobem wykonywania przez niego pracy (przyczyny dotyczące pracownika) - rzutujące na potrzebę świadczenia pracy na rzecz konkretnego pracodawcy ${ }^{15}$. Do tej kategorii można niewątpliwie zaliczyć spowodowaną pandemią złą sytuację finanso-

${ }^{14} \mathrm{Na}$ temat tej konstrukcji zob. zwłaszcza L. Foreк: Zakazy wypowiedzenia umowy o pracę. Warszawa 1976, s. 7-12.

${ }^{15} \mathrm{Z}$ jednej strony mogą one mieć charakter losowy (np. klęska żywiołowa), z drugiej zaś charakter finansowy (np. wysokie koszty pozyskania kredytów, ryzyko kursowe), gospodarczy (np. recesja) bądź polityczny (np. sankcje ekonomiczne wobec kraju importera towarów). Zob. wyrok Sądu Najwyższego z 10 marca 2016 r., III PK 81/15. 
wą pracodawcy, konieczność ograniczenia działania przedsiębiorstwa wskutek spadku zainteresowania określonymi dobrami czy usługami, wreszcie konsekwencje czasowego wstrzymania działalności pracodawcy. A contrario dopuszczalne jest natomiast wypowiedzenie lub rozwiązanie umowy o pracę z przyczyn dotyczących pracownika ${ }^{16}$. Prima facie może się wydawać, że ustawodawca posłużył się konstrukcją tzw. węższego zakazu (który obejmuje samą czynność prawna, ale nie jej skutek), co oznaczałoby, że pomimo otrzymania pomocy pracodawca mógłby rozwiązać umowę wypowiedzianą wcześniej. Taka wykładnia pozostawałaby jednak w oczywistej sprzeczności z celami regulacji, umożliwiając korzystanie z pomocy przez pracodawców, którzy podjęli działania mające na celu zwolnienia pracowników. Biorąc pod uwagę szczególny kontekst powstawania ustawy (tempo prac, stopień skomplikowania regulacji), być może w większym stopniu niż zazwyczaj należy dopuszczać modyfikację rezultatów wykładni językowo-logicznej przez wykładnię celowościową. Dlatego należy zaproponować (mając świadomość kontrowersji), że - pomimo literalnego brzmienia przepisu - pracodawca, który chce skorzystać ze wsparcia, nie tylko nie może wypowiedzieć, lecz również rozwiązać wcześniej wypowiedzianej umowy.

W sytuacji, w której dofinansowanie do wynagrodzeń pobierane jest na podstawie umowy ze starosta, ustawodawca posłużył się szerszą (a przy tym dość specyficzną) konstrukcją prawną. Pracodawca został zobowiązany do utrzymania $\mathrm{w}$ zatrudnieniu pracowników objętych umową. Obowiązek ten istnieje przez okres, na który zostało przyznane dofinansowanie (art. 15zzb ust. 8 ). Przez „utrzymanie w zatrudnieniu" należy rozumieć zakaz zakończenia stosunku pracy nie tylko z przyczyn niedotyczących pracownika i nie tylko w drodze wypowiedzenia dokonanego przez pracodawcę, ale w jakimkolwiek trybie. Wyjątek stanowią rozwiązanie umowy o pracę bez wypowiedzenia $\mathrm{z}$ winy pracownika (art. 52 k.p.) oraz wygaśnięcia stosunku pracy (art. 63 k.p.). Największe wątpliwości budzi stosunkowo krótki okres ochrony, który został ograniczony do okresu pobierania świadczeń, podczas gdy pierwotnie (w niektórych przypadkach) obejmował jeszcze 3 miesiące po jego zakończeniu. Takie rozwiązanie stanowiło

16 Szeroko na ten temat L. Mitrus: Wypowiedzenie umowy o prace z przyczyn dotyczacych pracownika. Warszawa 2018, s. 139 i n. 
prawdopodobnie odpowiedź na obawy pracodawców i próbę swoistego zachęcenia ich do korzystania z pomocy publicznej. Niewątpliwie osłabiło to jednak pozycję pracowników, którzy muszą liczyć jedynie na to, że w okresie pobierania dofinansowania sytuacja pracodawcy ulegnie poprawie na tyle, że nie będzie on zmuszony do redukcji zatrudnienia. Konsekwencją naruszenia ograniczeń (mających określony cel: zachowanie miejsc pracy) jest obowiązek zwrotu uzyskanej pomocy. Obowiązek ten został ograniczony do pomocy udzielonej na pracownika, wobec którego ograniczenia zostały naruszone. Jednocześnie przepisy wprowadzające ograniczenia są również przepisami dotyczącymi wypowiedzenia lub rozwiązania umowy o pracę, a zatem ich naruszenie należy kwalifikować jako naruszenie przepisów odpowiednio: o wypowiadaniu umów o pracę (art. 45 k.p.) albo o rozwiązywaniu umów o pracę (art. 56 k.p.).

\section{Rozwiązywanie stosunków pracy}

Pomimo uzyskanego wsparcia oraz formalnych ograniczeń w rozwiązywaniu stosunków pracy przynajmniej część pracodawców dotkniętych pandemią i spowodowanym przez nią pogorszeniem się sytuacji gospodarczej stanęła przed koniecznością redukcji zatrudnienia. W przypadku pracowników nieobjętych dofinansowaniem, a także pracowników, w stosunku do których okres pobierania dofinansowania już upłynął, pracodawca może dokonać wypowiedzeń z przyczyn niedotyczących pracowników. W odniesieniu do pracodawców zatrudniających co najmniej 20 pracowników może to oznaczać wejście w reżim prawny u.z.g. i w rezultacie: 1) zwolnienia grupowe (art. 1 u.z.g.) albo 2) indywidualne zwolnienia z przyczyn niedotyczących pracowników, jeśli przyczyny te stanowiły wyłączny powód rozwiązania stosunku pracy (art. 10 ust. 1 u.z.g.). Zakres stosowania przepisów regulujących zwolnienia z przyczyn niedotyczących pracowników został ograniczony do osób formalnie pozostających stroną stosunku pracy (art. 2 k.p.). Mechanizmami ochronny$\mathrm{mi}, \mathrm{w}$ tym procedurą zwolnień grupowych, nie są więc objęte osoby wykonujące pracę na innej podstawie niż stosunek pracy: nawet jeśli stosuje się do nich mechanizmy przewidziane w tarczy antykryzysowej, a ich sytuacja (w tym sytuacja na rynku pracy) jest zbliżona 
do sytuacji pracowników ${ }^{17}$. Rozszerzenie zakresu pewnych mechanizmów (np. procedury zwolnień grupowych) oznaczałoby jednak ochronę przed rozwiązaniem umów cywilnoprawnych, na co (z pewnymi wyjątkami ${ }^{18}$ ) ustawodawca nie jest jeszcze gotowy. Pracodawcy, zatrudniający mniej niż 20 pracowników, będą dokonywać zwolnień na zasadach wynikających z k.p. (a zatem bez obciążeń, ale też bez ułatwień wynikających z u.z.g.).

Szczególną przyczyną zwolnień z przyczyn niedotyczących pracowników jest upadłość lub likwidacja pracodawcy, prowadzące do całkowitego zniesienia zakładu pracy. Charakter środków służących przeciwdziałaniu pandemii (ograniczanie, nawet zamykanie niektórych sektorów gospodarki) może (a nawet musi) prowadzić do zwiększenia się liczby takich przypadków, zwłaszcza w sferach najbardziej dotkniętych ograniczeniami (gastronomia, hotelarstwo, sport i rekreacja). Ustanie stosunków pracy nie następuje w takiej sytuacji z mocy prawa, lecz wymaga ich rozwiązania przez strony ${ }^{19}$. Dlatego ustawodawca, z jednej strony, ułatwia zwolnienia, wyłączając powszechną oraz szczególną ochronę przed wypowiedzeniem (art. $41^{1}$ k.p.), z drugiej, wymaga (w razie spełnienia ustawowych przesłanek) przeprowadzenia procedury zwolnień grupowych. Wszyscy pracodawcy dokonujący zwolnień z przyczyn niedotyczących pracowników mają możliwość skrócenia 3-miesięcznego okresu wypowiedzenia do miesiąca (art. $36^{1}$ k.p.). W praktyce pojawiała się wątpliwość, czy skrócenie okresu wypowiedzenia jest możliwe również $\mathrm{w}$ razie wypowiedzenia warunków pracy i płacy, do którego stosuje się przepisy o wypowiedzeniu definitywnym (art. $42 \S 1$ k.p.). W przypadku wypowiedzenia definitywnego skrócenie okresu wypowiedzenia umożliwia

17 Problem ten ustawodawca starał się w pewien sposób uwzględnić w ramach tarcz antykryzysowych, przewidując pewne formy wsparcia dla osób zatrudnionych poza stosunkiem pracy, jak również wspierając podmioty, które osoby te zatrudniają (w sposób analogiczny do wsparcia pracodawców sensu stricto).

18 Taki wyjątek stanowi ochrona trwałości zatrudnienia działacza związkowego (art. 32 u.z.z.). W wyniku reformy z 2018 r. ochronę tę rozszerzono na działaczy związkowych zatrudnionych na innej podstawie niż stosunek pracy. Na ten temat zob. m.in. K.W. BARAn: Refleksje o ochronie stosunku zatrudnienia działaczy zwiazkowych na poziomie zakładowym po nowelizacji ustawy zwiazkowej z 5 lipca 2018 r. „Praca i Zabezpieczenie Społeczne" 2018, nr 10.

19 Szeroko na ten temat A. Toмаneк: Stosunki pracy w razie likwidacji i upadłości pracodawcy. Warszawa 2012, s. 196 i n. 
szybsze zwolnienie pracownika, nie zagrażając jednak jego interesom majątkowym (odszkodowanie w wysokości wynagrodzenia za okres skrócenia). W przypadku wypowiedzenia warunków pracy i płacy oznaczałoby ono po prostu skrócenie okresu przejściowego, w którym pracownik zachowuje dotychczasowe warunki zatrudnienia. Taki skutek musiałby zostać wyraźnie przewidziany przez ustawodawcę. Dlatego zarówno konstrukcja, jak i cel art. $36^{1}$ k.p. przemawiają za jego stosowaniem tylko do wypowiedzenia umowy o pracę (jednak już nie do wypowiedzenia warunków pracy i płacy).

Jeśli liczba zwolnień z przyczyn niedotyczących pracowników przekracza progi określone w art. 1 ust. 1 u.z.g., zwolnienia będą kwalifikowane jako zwolnienia grupowe, a na pracodawcy będzie ciążyć obowiązek przeprowadzenia procedury obejmującej pewne formy współdziałania z przedstawicielami pracowników oraz informowania organu zatrudnienia (powiatowego urzędu pracy). Szybkie tempo zmian wywołanych pandemią może powodować, że pracodawcom będzie trudniej rozłożyć w czasie planowane zwolnienia, tak aby uniknąć wejścia w reżim prawny zwolnień grupowych. W praktyce problemem okazuje się już samo stwierdzenie zwolnienia grupowego. Wątpliwości dotyczą przede wszystkim kwalifikacji wypowiedzeń zmieniających (art. 42 §1-3 k.p.), których liczba może rosnąć wraz z pogarszaniem się sytuacji gospodarczej. Jednocześnie ich wliczanie do zwolnienia grupowego nie jest oczywiste ${ }^{20}$. Stąd konieczność odwołania się do kryteriów sformułowanych przez TS UE na gruncie dyrektywy 98/5921. Zdaniem Trybunału zwolnieniem w rozumieniu art. 1 ust. 1 lit. a dyrektywy 98/59 jest również dokonanie przez pracodawcę jednostronnej i niekorzystnej dla pracownika zasadniczej zmiany istotnych elementów jego umowy o pracę z powodów niezwiązanych

${ }^{20}$ Co prawda do wypowiedzenia warunków pracy i płacy stosuje się przepisy o wypowiedzeniu umowy (art. $42 \S 1$ k.p.), to jednak widoczne były tendencje, aby przynajmniej $\mathrm{w}$ niektórych sytuacjach wypowiedzeń zmieniających nie wliczać do zwolnień grupowych.

${ }^{21}$ Dyrektywa Rady nr 98/59/WE z dnia 20 lipca 1998 r. w sprawie zbliżania ustawodawstw państw członkowskich odnoszących się do zwolnień grupowych. Artykuł 1 ust. 1 dyrektywy 98/59 stanowi, że jako zwolnienia traktuje się także inne formy ustania umowy o pracę, które następują z inicjatywy pracodawcy, z jednego lub więcej powodów niezwiązanych z poszczególnym pracownikiem, pod warunkiem że zwolnień tych jest co najmniej pięć. 
$\mathrm{z}$ tym pracownikiem ${ }^{22}$. Już $\mathrm{w}$ kontekście polskiej regulacji (charakterystycznej ze względu na potencjalny skutek wypowiedzenia warunków pracy i płacy jakim jest rozwiązanie umowy) Trybunał stwierdził, że art. 1 ust. 1 należy interpretować $w$ ten sposób, że jednostronną zmianę przez pracodawcę warunków wynagrodzenia na niekorzyść pracowników - która to zmiana, w wypadku odmowy jej przyjęcia przez pracownika, prowadzi do wygaśnięcia umowy o pracę - należy uznać za "zwolnienie" w rozumieniu tego przepisu ${ }^{23}$. Odniesienie się do potencjalnego skutku wypowiedzenia zmieniającego (rozwiązanie umowy) mogłoby sugerować, że to właśnie ten skutek będzie decydujący dla zaliczenia czynności pracodawcy do zwolnienia grupowego ${ }^{24}$. Jednocześnie jednak obowiązek przeprowadzenia procedury zwolnienia grupowego powstaje przed podjęciem przez pracodawcę decyzji o rozwiązaniu umów o pracę (co ma bezpośredni związek z realizacją celów dyrektywy $)^{25}$. Dlatego ocena i kwalifikacja wypowiedzeń zmieniających musi być dokonywana ex ante, z uwzględnieniem wpływu tych czynności na sytuację pracownika (poważne pogorszenie istotnych warunków zatrudnienia) ${ }^{26}$. Jednak nawet gdyby wypowiedzenie zmieniające $w$ chwili jego dokonywania nie zostało uznane za zwolnienie $\mathrm{w}$ rozumieniu dyrektywy, to jeśli wskutek odmowy zaproponowanych warunków pracy i płacy umowa ulegnie rozwiązaniu, może być co do zasady uznane za inny sposób ustania stosunku pracy (wliczany

${ }_{22}$ Wyrok TS UE z dnia 11 listopada 2015 r., Pujante Rivera, C-422/14, EU:C:2015:743, pkt 55.

${ }^{23}$ Wyrok TS UE z dnia 21 września 2017 r., Ciupa i in., C-429/16, ECLI:EU:C:2017:711. $\mathrm{W}$ rezultacie pracodawca ma obowiązek przeprowadzenia przewidzianych $\mathrm{w}$ tym przepisie konsultacji w sytuacji, gdy ma on zamiar wprowadzenia takiej jednostronnej zmiany warunków wynagrodzenia, pod warunkiem spełnienia przesłanek przewidzianych w art. 1 wskazanej dyrektywy, czego ustalenie jest zadaniem sądu odsyłającego.

${ }^{24}$ Por. wyrok SN z dnia 10 października 2019 r., I PK 196/18, OSNP 2020, nr 9, poz. 92.

${ }_{25}$ Zob. wyroki z dnia 27 stycznia 2005 r., Junk, C-188/03, EU:C:2005:59, pkt 37 i 38, oraz z dnia 10 września 2009 r., Akavan Erityisalojen Keskusliitto AEK i in., C-44/08, EU:C:2009:533, pkt 38 i 46.

${ }^{26}$ Zwolnieniem w rozumieniu dyrektywy nie będą dokonane przez pracodawcę z przyczyn niedotyczących pracowników: niekorzystna dla pracownika zmiana istotnego warunku zatrudnienia, ale niepowodująca zasadniczego pogorszenia sytuacji pracownika, jak również zmiana nieistotnego elementu umowy o pracę (wyrok TS UE z dnia 21 września 2017 r., Ciupa i in., C-429/16, ECLI:EU:C:2017:711, pkt 28). Przeciwko uznaniu za zwolnienie może w szczególności przemawiać czasowy charakter zmiany (pkt 29). 
do zwolnienia grupowego, jeśli zwolnień właściwych jest co najmniej pięć $)^{27}$. Może to powodować stan niepewności po stronie pracodawcy i w praktyce stanowić argument za przeprowadzeniem procedury zwolnień grupowych (z obawy przed zarzutem naruszenia przepisów o wypowiadaniu umów o pracę).

W warunkach pandemii i towarzyszącego jej stanu niepewności oraz pogarszającej się sytuacji na rynku pracy procedura zwolnień grupowych (której celem jest uniknięcie zwolnień lub ograniczenie ich rozmiaru, $\mathrm{a}-\mathrm{w}$ zakresie, $\mathrm{w}$ jakim nie będzie to możliwe - łagodzenie ich skutków) ma szczególne znaczenie. Dużą rolę mają do odegrania uczestniczący w procedurze przedstawiciele pracowników - zakładowe organizacje związkowe, nawet przedstawiciele pracowników wyłonieni w trybie przyjętym u danego pracodawcy ( $\mathrm{z}$ braku związków zawodowych). W szczególności mogą oni proponować zastosowanie rozwiązań, stanowiących próbę wyważenia interesów pracodawcy oraz zatrudnianych przez niego pracowników (zgoda na przejściowe pogorszenie sytuacji pracowników w nadziei uniknięcia zwolnień lub ograniczenia ich zakresu). Strona pracownicza może proponować skorzystanie ze szczególnych mechanizmów antykryzysowych, $\mathrm{w}$ tym przestoju ekonomicznego lub obniżenia czasu pracy (które są formą udziału pracowników w przezwyciężaniu skutków kryzysu), jednocześnie zachęcając pracodawcę do ubiegania się o pomoc finansową. Partnerzy społeczni mogą też korzystać z mechanizmów przewidzianych $\mathrm{w}$ kodeksie pracy: porozumień $\mathrm{w}$ sprawie zawieszenia postanowień układów zbiorowych pracy (art. $241^{27}$ k.p.) lub innych aktów autonomicznych (art. $9^{1}$ k.p.), ewentualnie zmiany warunków zatrudnienia wynikających z umów o pracę (art. $23^{1 a}$ k.p.). Możliwe są również działania służące uelastycznieniu stosunku pracy, np. dzięki wydłużeniu okresów rozliczeniowych (art. 129 w zw. z art. 150 k.p.).

O ile same zasady rozwiązywania umów oraz procedura zwolnień grupowych nie zostały ani wyłączone, ani zasadniczo zmodyfikowane, ich stosowanie $\mathrm{w}$ czasie pandemii może wymagać swoistego dostosowania. Podobnie jak $\mathrm{w}$ innych sferach, podstawową wartością jest ochrona życia i zdrowia osób zaangażowanych. Dlatego należy

27 Por. wyrok TS UE z dnia 21 września 2017 r., Ciupa i in., C-429/16, ECLI:EU:C: 2017:711, pkt 31 oraz wyrok SN z dnia 10 października 2019 r., I PK 196/18, OSNP 2020, nr 9, poz. 92. 
oczekiwać wzrostu znaczenia różnych form komunikacji na odległość. W tym kontekście należy odróżnić przypadki, gdy ustawa wymaga zachowania formy pisemnej (rozwiązanie i wypowiedzenie umowy o pracę, przekazywanie informacji przedstawicielom pracowników oraz powiatowemu urzędowi pracy $\mathrm{w}$ ramach procedury zwolnień grupowych) oraz sytuacje, gdy brak jest takiego wymogu. W przypadkach, gdy wymagane jest zachowanie formy pisemnej, pracodawca musi spowodować dostarczenie podpisanego tradycyjnie dokumentu, a - chcąc korzystać ze środków komunikacji elektronicznej - musi posługiwać się kwalifikowanym podpisem elektronicznym.

Wydaje się, że pandemia będzie kolejnym z czynników skłaniających do refleksji na temat potrzeby przebudowy formalnych aspektów funkcjonowania obrotu prawnego w sferze zatrudnienia. Co ciekawe, wymóg formy pisemnej nie został sformułowany $w$ odniesieniu do porozumienia oraz regulaminu zwolnień grupowych. Niemniej jednak ze względu na ich charakter prawny (zaliczenie do prawa pracy $w$ rozumieniu art. $9 \S 1$ k.p.), należy oczekiwać, że dojdą one do skutku w sposób niebudzący wątpliwości i zostaną udostępnione osobom zainteresowanym, w tym zwłaszcza pracownikom dotkniętym zwolnieniami. Co do zasady możliwe jest natomiast wykorzystywanie różnych form komunikacji na odległość dla organizacji spotkań partnerów społecznych, w tym spotkań $\mathrm{w}$ ramach procedury zwolnień grupowych. Kwestia ta jest bardziej złożona, jeśli obowiązujące u pracodawcy porozumienie o współpracy ze związkiem zawodowym (związkami zawodowymi) wymaga określonych form współdziałania. Wówczas konieczna wydaje się zmiana tego porozumienia. Za wystarczające, zwłaszcza ze względu na kontekst funkcjonowania relacji zbiorowych w okresie pandemii, należy uznać zgodne działanie stron.

Zmianie nie ulegają zasady określenia kryteriów doboru do zwolnienia, które stanowią jeden $\mathrm{z}$ najważniejszych elementów aktów kończących procedurę ${ }^{28}$. W kontekście szczególnej sytuacji spowodowanej pandemią może się jednak zwiększać znaczenie kryteriów odnoszących się do osobistej sytuacji pracownika (stan i obowiązek utrzymania rodziny, zwłaszcza samotne wychowywanie dzieci czy

${ }^{28}$ Kryteria mogą być różnorodne, przy czym powinny być obiektywne, niedyskryminujące i sprawiedliwe (por. wyrok Sądu Najwyższego z 1 czerwca 2012 r., I PK 258/11). 
niepełnosprawność, a także posiadanie innych źródeł dochodów czy łatwość w znalezieniu nowego zatrudnienia), które, co do zasady są uwzględniane pomocniczo ${ }^{29}$. W czasie pandemii częstsze są również przypadki niemożności wypowiedzenia umowy pracownikom wytypowanym do zwolnienia, ale korzystającym $\mathrm{z}$ ochrony przed wypowiedzeniem umowy o pracę, $\mathrm{w}$ tym ze względu na usprawiedliwioną nieobecność w pracy (art. 41 k.p.) ${ }^{30}$. Jeśli liczba pracowników pozostałych do zwolnienia okaże się mniejsza niż progi zwolnienia grupowego, a minął 30-dniowy termin od dnia złożenia pierwszego wypowiedzenia (względnie zawarcia porozumienia) powstaje pytanie, czy pracownik nadal może być zwolniony w ramach zwolnienia grupowego, czy konieczne jest skorzystanie z trybu zwolnienia indywidulanego z przyczyn niedotyczących pracowników. Wydaje się, że brak spełnienia przesłanki liczby zwalnianych pracowników w stosunku do pracowników powracających do pracy, np. po chorobie, nie niweczy możliwości rozwiązania $\mathrm{z}$ nimi stosunków pracy $\mathrm{w}$ ramach grupowego zwolnienia. Przemawia za tym w szczególności fakt objęcia tych pracowników zwolnieniem grupowym (wskazanie na liście do zwolnienia), zwłaszcza gdy okres, w ciągu którego miały nastąpić zwolnienia grupowe, jeszcze nie upłynął ${ }^{31}$.

\section{Uprawnienia zwalnianych pracowników}

Jakkolwiek dotychczas nie doszło do poważniejszego załamania na rynku pracy, należy się liczyć z niekorzystnymi zmianami sytuacji,

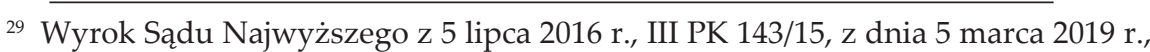
I BP 10/17; K.W. BARAN (red.): Zbiorowe prawo zatrudnienia. Komentarz, Warszawa 2019. W tym kontekście warto zwrócić uwagę, że wybór pracownika do zwolnienia może być uznany za sprzeczny z zasadami współżycia społecznego, gdy sytuacja osobista zwolnionego pracownika jest znacznie gorsza niż pozostałych osób zatrudnionych na stanowiskach objętych redukcją (wyrok Sądu Najwyższego z 19 grudnia 1996 r., I PKN 46/96).

${ }^{30}$ Zwolnienie lekarskie nie chroni pracownika przed rozwiązaniem stosunku pracy tylko wówczas, gdy upłynęły okresy wskazane w art. 53 k.p.

${ }^{31}$ Poza tym takie rozwiązanie, może okazać się korzystniejsze dla pracowników. Zdarza się, że w porozumieniach (regulaminach) dotyczących zwolnień grupowych, przewiduje się świadczenia dodatkowe dla zwalnianych pracowników (np. rekompensaty). Jednocześnie, na mocy art. 9, mają oni prawo ponownego zatrudnienia, w przypadku zatrudniania w tej samej grupie zawodowej. 
i przygotować rozwiązania zapewniające adekwatną ochronę pracownikom (również innym osobom tracącym pracę). Starając się łagodzić obciążenia pracodawców, państwo powinno zwiększać swój udział w tworzeniu zabezpieczeń, tym bardziej, że zwolnienia - przynajmniej do pewnego stopnia - stanowią konsekwencję decyzji państwa (wstrzymanie lub ograniczenie działalności w niektórych sferach). Jedną $\mathrm{z}$ takich form pomocy był dodatek solidarnościowy dla osób, których stosunki pracy zostały wypowiedziane przez pracodawcę lub uległy rozwiązaniu wskutek upływu czasu po 15 marca 2020 r. ${ }^{32}$ Ustawodawca podwyższył także zasiłki dla bezrobotnych ${ }^{33}$, w tym umożliwił zaliczenie do okresu pracy, warunkującego możliwość nabycia prawa do takiego zasiłku, okresu pracy w obniżonym wymiarze etatu na podstawie art. $15 \mathrm{~g}$ u.z.p.z., w których pracownik otrzymywał wynagrodzenie niższe od wynagrodzenia minimalnego. Uelastyczniono także procedurę rejestracji dla osób bezrobotnych i poszukujących pracy ${ }^{34}$.

Kluczowym elementem ochrony pracowników pozostają jednak odprawy pieniężne, przysługujące $\mathrm{z}$ tytułu rozwiązania umowy o pracę z przyczyn niedotyczących pracowników (art. $8 \mathrm{w}$ zw. z art. 10 ust. 1 u.z.g.). Odprawa do pewnego stopnia łagodzi utratę miejsca pracy i zapewnia środki utrzymania po ustaniu zatrudnienia. Jakkolwiek cele te są aktualne (a może nawet szczególnie aktualne) w kontekście kryzysu pandemicznego, jednocześnie muszą być konfrontowane $\mathrm{z}$ dążeniem do zapewnienia wsparcia pracodawcom, zwłaszcza tym, którzy znaleźli się w najtrudniejszym położeniu. Ważąc te dwie wartości, ustawodawca uznał, że ochrona pracowników w określonych (kwalifikowanych) sytuacjach ustępuje pierwszeństwa ochronie pracodawcy ${ }^{35}$. Zgodnie z art. 15 gd u.z.p.z., w okresie obowiązywania stanu zagrożenia epidemicznego albo stanu epidemii, ogłoszonego z powodu COVID-19, w przypadku wystąpienia u pracodawcy spad-

32 Dodatek przysługiwał w wysokości 1400 zł przez okres nieprzekraczający 3 miesięcy (niewliczany do okresu wypłaty zasiłku dla bezrobotnych). Wypłaty dodatku dokonywał ZUS ze środków FP zasilanego z Funduszu Przeciwdziałania COVID-19.

33 Od 1 września 2020 r., przez pierwsze 90 dni zasiłek dla bezrobotnych, w podstawowej wysokości, wynosi 1200 zł brutto, w sytuacji gdy od 1 czerwca 2020 r. przez pierwsze 90 dni wynosił 881,20 zł brutto.

34 Rozporządzenie Ministra Rodziny, Pracy i Polityki Społecznej z dnia 14 kwietnia 2020 r. w sprawie rejestracji bezrobotnych i poszukujących pracy.

${ }_{35}$ M. MęDrala: Ograniczenia praw zatrudnionych w tarczy 4.0 - niektóre refleksje w kontekście zasad konstytucyjnych. „Monitor Prawa Pracy” 2020, nr 9, s. 7 i n. 
ku obrotów gospodarczych lub istotnego wzrostu obciążenia funduszu wynagrodzeń, wysokość odprawy nie może przekroczyć dziesięciokrotności minimalnego wynagrodzenia za pracę (podczas gdy - co do zasady - jest to piętnastokrotność wynagrodzenia minimalnego). Rozumiejąc chęć wsparcia pracodawców, którzy znaleźli się w najtrudniejszej sytuacji (a pośrednio również wolę ochrony miejsc pracy) trudno nie zauważyć, że takie rozwiązanie oznacza dodatkowe obciążenie skutkami pandemii pracowników, i to w szczególnie trudnym dla nich momencie. Państwo, chcąc zapewnić wsparcie pracodawcom, ale jednocześnie dążąc do zachowania równowagi społecznej, powinno przejąć ekonomiczny ciężar tych świadczeń, tym bardziej, że jest jeszcze za wcześnie, aby ocenić efektywność innych działań osłonowych, które mogłyby zrównoważyć osłabienie ochrony w ramach samego stosunku pracy.

\section{Restrukturyzacja zatrudnienia $\mathrm{w}$ administracji}

Odrębnej refleksji wymagają rozwiązania, które w regulacjach antykryzysowych zostały przyjęte $\mathrm{w}$ stosunku do sektora publicznego. W imię solidarności konstytucyjnej ${ }^{36}$, ustawodawca planował obniżenie kosztów działania administracji, ułatwiając pogarszanie warunków zatrudnienia ( $w$ tym obniżanie wynagrodzeń), a także zwalnianie pracowników. W razie zagrożenia dla finansów publicznych państwa Rada Ministrów, w drodze rozporządzenia (które dotychczas nie zostało wydane), może nie tylko przewidzieć stosowanie mniej korzystnych warunków zatrudnienia u określonych pracodawców, lecz również nałożyć na te podmioty obowiązek zmniejszenia zatrudnienia (art. 15zzzzzo u.z.p.z). W odniesieniu do zwolnień przeprowadzanych w tym trybie, wyłączono stosowanie u.z.g., tworząc szczególne mechanizmy osłonowe (gwarantujące jednak znacznie niższy poziom ochrony). Przede wszystkim strona pracownicza została pozbawiona realnego wpływu na podejmowane działania ${ }^{37}$. Rola związków zawo-

${ }^{36}$ Uzasadnienie rządowego projektu ustawy o szczególnych instrumentach wsparcia w związku z rozprzestrzenianiem się wirusa SARS-CoV-2, druk 330, s. 73.

${ }^{37} \mathrm{~K}$. WalczaK wskazuje, że ,jest to [...] w praktyce czysta fikcja, tym bardziej że ustawa nie wskazuje, co z taką opinią miałaby zrobić osoba odpowiadająca za sprawy personalne. $W$ świetle całokształtu przepisów wydaje się, że nie tylko nie musi nic 
dowych została ograniczona do możliwości wyrażenia opinii o proponowanym sposobie zmniejszenia zatrudnienia, ale bez prawa do zawarcia porozumienia regulującego zasady zwolnień (art. 15zzzzzr ust. 5 i 6 u.z.p.z.). Wyłączono także stosowanie procedury wynikającej $\mathrm{z}$ art. 38 k.p. Jednocześnie połączono to z brakiem konieczności notyfikowania urzędom pracy informacji o zwolnieniach (co w kontekście skutków dla lokalnego rynku pracy jest niezrozumiałe), a także pozbawiono zwalnianych pracowników prawa do ponownego zatrudnienia w przypadku prowadzenia nowych naborów. Wykorzystanie w praktyce mechanizmu restrukturyzacji zatrudnienia oznaczałoby zasadnicze pogorszenie sytuacji pracowników sektora publicznego, szczególnie niebezpieczne wobec ich sytuacji na rynku pracy, w tym trudności w znalezieniu nowego zatrudnienia (dotyczy to również długoletnich pracowników administracji) ${ }^{38}$.

Zastrzeżenia budzą także inne zastosowane mechanizmy, m.in. możliwość zwalniania urzędników mianowanych oraz części pracowników objętych szczególną ochroną. Wreszcie, w specyficzny sposób ukształtowano kryteria doboru pracowników administracji do zwolnienia, z jednej strony wskazano bowiem kryteria podstawowe, związane ze stosunkiem pracy, oraz kryteria pomocnicze, uwzględniające sytuację osobistą i rodzinną pracownika, z drugiej strony natomiast przewidziano, że $\mathrm{w}$ pierwszej kolejności zwolnienia obejmą pracowników posiadających ustalone prawo do emerytury lub renty (art. 15zzzzzq ust. 1 pkt 1 u.z.p.z.).

Zaproponowany mechanizm to bezprecedensowa ingerencja w trwałość zatrudnienia pracowników sektora publicznego. Ustawodawca, uznając się niejako za pośredniego pracodawcę, ułatwia sobie możliwość przeprowadzenia redukcji zatrudnienia. W pewien sposób planuje więc scenariusz odmienny niż realizowany w innych sferach: zwolnienia pracowników, a nie dążenia do utrzymania zatrudnienia. Powstaje wrażenie, że pracownicy sektora publicznego w pewien sposób mają ponieść koszty zachowania miejsc pracy $\mathrm{w}$ innych sferach. Jest to o tyle specyficzne, że stabilność zatrudnienia fachowej kadry

robić, ale też $\mathrm{w}$ zasadzie nie może, skoro również jej autonomia w tym zakresie jest iluzoryczna” - zob. "Optymalizacja” kosztów zatrudnienia w administracji rzadowej. „Studia z Zakresu Prawa Pracy i Polityki Społecznej” 2020, nr 27 (4), s. 293-303.

${ }^{38}$ K. WalczaK: Kilka uwag na temat zatrudnienia w dobie pandemii i po jej zakończeniu. „Monitor Prawa Pracy” 2020, nr 6, s. 9 i n. 
urzędniczej wpływa na skuteczność jej działań, a wielokrotnie stanowi kryterium wyboru jednostek administracji publicznej jako pracodawców. Zaproponowane rozwiązanie racjonalizatorskie może mieć zatem daleko idące skutki nie tylko dla samych pracowników administracji, ale także obywateli, którzy korzystają $\mathrm{z}$ usług administracji ${ }^{39}$. Podejmując działania proaktywne wobec sektora prywatnego, ustawodawca nie powinien zatem rezygnować $\mathrm{z}$ ochrony miejsc pracy $\mathrm{w}$ sektorze publicznym, na który ma największe możliwości oddziaływania (w tym oddziaływania prawnego). Nawet jeśli uniknięcie redukcji zatrudnienia nie będzie możliwe, należy jej dokonywać w sposób zapewniający najszerszą możliwą ochronę zwalnianym pracownikom (zarówno gdy chodzi o stosowane mechanizmy autonomiczne, jak i ustawowy system wsparcia). Można mieć jedynie nadzieję, że mechanizmy przewidziane $\mathrm{w}$ tarczy antykryzysowej w praktyce nie zostaną wykorzystane.

\section{Zakończenie}

Pomimo skali kryzysu pandemicznego oraz jego potencjalnych skutków dla rynku pracy ustawodawca nie zdecydował się na stworzenie kompleksowej regulacji zwolnień z przyczyn niedotyczących pracowników. Zastosowanie znajdują przepisy powszechnego prawa pracy, których zdolność adaptacyjna okazywała się do tej pory wystarczająca. Konstrukcja przepisów szczególnych jest stosowana tylko punktowo, w sferach, w których realizowane są specyficzne cele ustawodawstwa antykryzysowego. Dotyczy to stabilizacji zatrudnienia, powiązanej ze skorzystaniem z pomocy publicznej, instrumentów rynku pracy oraz zmian $\mathrm{w}$ administracji publicznej. Nie zmieniają się natomiast: procedura zwolnień grupowych oraz zasady rozwiązywania stosunków pracy. Jakkolwiek pojawiają się pewne wątpliwości interpretacyjne (przykładem problem stosowanego mechanizmu ochrony stosunków pracy), to jednak ze względu na ograniczony zakres modyfikacji regulacja zachowuje spójność konstrukcyjną. Jednocześnie szczególne warunki panujące $\mathrm{w}$ okresie pandemii będą wpływać na praktykę relacji zbiorowych oraz sposób działania pracodawców, m.in. przyczyniając

39 J. Szmit: Państwo wobec pracowników administracji rządowej (uwagi na tle ustawy antykryzysowej). „Państwo i Prawo” 2020, nr 12, s. 100-105. 
się do wzrostu znaczenia form zdalnych (zarówno w zakresie relacji między partnerami społecznymi, jak i dokonywania czynności prawnych). Obecne rozwiązanie może się okazać niewystarczające w razie pogorszenia się sytuacji na rynku i zwiększenia się liczby zwolnień. Wówczas konieczne może się okazać szersze wykorzystanie konstrukcji szczególnych, a nawet stworzenie kompleksowej regulacji zwolnień w warunkach kryzysu pandemicznego.

Dużo większe wątpliwości budzi spójność teleologiczna, w tym umiejętność znalezienia właściwych proporcji między realizacją poszczególnych celów. W obliczu kryzysu pandemicznego i towarzyszących mu zwolnień pracowników ustawodawca skoncentrował się na działaniach służących wsparciu pracodawców, a w rezultacie też mających się przyczyniać do zachowania miejsc pracy. Niestety, część konsekwencji wsparcia pracodawców ponoszą pracownicy, których warunki zatrudnienia ulegają pogorszeniu, co nie jest rekompensowane ze środków publicznych. Co więcej, formalne gwarancje trwałości zatrudnienia zostały ograniczone tylko do okresu pobierania świadczeń przez pracodawców. Za formę ochrony interesów pracodawcy można również uznać ograniczenie wysokości odpraw. Osłabienie tego aspektu ochrony, może (ale chyba tylko częściowo) być rekompensowane przez nowe (zmodyfikowane) rozwiązania w sferze promocji zatrudnienia. Wszystko to powoduje pewne zachwianie równowagi między stronami stosunku pracy. W szczególnej sytuacji znaleźli się pracownicy zatrudnieni $\mathrm{w}$ administracji publicznej (i niektórych innych podmiotach - art. 15zzzzzp ust. 1 u.z.p.z.). W ich przypadku ustawodawca wprost ogranicza ochronę przed zwolnieniem oraz procedurę zbiorową. Państwo, mające największe możliwości reagowania na kryzys, zapowiada zwolnienia w sferze publicznej, w pewnym sensie przenosząc konsekwencje kryzysu na pracowników tam zatrudnionych i pod pewnymi względami kształtując ich sytuację w sposób mniej korzystny niż w sektorze prywatnym. Jest to niewątpliwie największa niespójność między celami działań antykryzysowych a rozwiązaniami przyjętymi w sferze zwolnień z przyczyn niedotyczących pracowników. Wobec pojawiających się kontrowersji można mieć nadzieję, że ustawodawca nie skorzysta $\mathrm{w}$ praktyce $\mathrm{z}$ tego mechanizmu. 


\section{Bibliografia}

\section{Literatura}

BARAN K.W.: Refleksje o ochronie stosunku zatrudnienia działaczy zwiazkowych na poziomie zakładowym po nowelizacji ustawy zwiazkowej z 5 lipca 2018 r. „Praca i Zabezpieczenie Społeczne" 2018, nr 10.

BARAN K.W. (red.): Zbiorowe prawo zatrudnienia. Komentarz. Warszawa 2019.

Duda K.: Sytuacja na rynku pracy w dobie pandemii koronawirusa. Raport. Wydział Polityki Społecznej, Rynku Pracy, Ubezpieczeń i Zdrowia OPZZ, 2020.

FlorczaK I.: COVID-19 and Labour Law: Poland. „Italian Labour Law e-Journal” 2020, vol. 13, nr 1.

FLOREK L.: Zakazy wypowiedzenia umowy o prace. Warszawa 1976.

ILO Monitor: COVID-19 and the world of work. Seventh edition, 21 January 2021.

KowalczyK G.: Rynek pracy trzyma się nieźle. „Dziennik Gazeta Prawna” 23.11.2020.

Kowalczyк G.: Wrzesień był najlepszy, ale trudno o dalsza poprawę. Nowa odsłona pandemii uderzy w rynek. „Dziennik Gazeta Prawna” 15.10.2020.

Latos-Mıєкowska M.: Porozumienia zbiorowe w tarczy antykryzysowej. „Praca i Zabezpieczenie Społeczne" 2020, nr 10.

MęDrala M.: Ograniczenia praw zatrudnionych w tarczy 4.0 - niektóre refleksje w kontekście zasad konstytucyjnych. „Monitor Prawa Pracy” 2020, nr 9.

Mitrus L.: Wypowiedzenie umowy o prace z przyczyn dotyczacych pracownika. Warszawa 2018.

Perulli A.: Regards comparés sur le droit social à l'épreuve du covid-19. „Revue de Droit du Travail” 2020, nr 4.

Raczkowski M., Ducki M.: Porozumienia zawieszajace w ustawie antykryzysowej. „Praca i Zabezpieczenie Społeczne” 2020, nr 5.

SKĄPSKi M.: Ochronna funkcja prawa pracy w gospodarce rynkowej. Kraków 2006

Szmit J.: Państwo wobec pracowników administracji rządowej (uwagi na tle ustawy antykryzysowej). „Państwo i Prawo” 2020, nr 12.

Tomanek A.: Stosunki pracy w razie likwidacji i upadłości pracodawcy. Warszawa 2012.

WalczaK K.: "Optymalizacja” kosztów zatrudnienia w administracji rządowej. „Studia z Zakresu Prawa Pracy i Polityki Społecznej” 2020, nr 4.

WalczaK K.: Kilka uwag na temat zatrudnienia w dobie pandemii i po jej zakończeniu. „Monitor Prawa Pracy” 2020, nr 6.

\section{Orzecznictwo}

Wyrok Sądu Najwyższego z 19 grudnia 1996 r., I PKN 46/96, OSNP 1997/15/273. Wyrok TS UE z dnia 27 stycznia 2005 r., Junk, C-188/03, EU:C:2005:59.

Wyrok TS UE z dnia 10 września 2009 r., Akavan Erityisalojen Keskusliitto AEK i in., C-44/08, EU:C:2009:533. 
Wyrok SN z dnia 1 czerwca 2012 r., I PK 258/11, LEX nr 1228589.

Wyrok TS UE z dnia 11 listopada 2015 r., Pujante Rivera, C-422/14, EU:C:2015:743, pkt 55.

Wyrok SN z dnia 10 marca 2016 r., III PK 81/15, OSNP 2017/10/12.

Wyrok Sądu Najwyższego z 5 lipca 2016 r., III PK 143/15, LEX nr 2073926.

Wyrok TS UE z dnia 21 września 2017 r., Ciupa i in., C-429/16, ECLI:EU: C:2017:711.

Wyrok z dnia 5 marca 2019 r., I BP 10/17, LEX nr 2632308.

Wyrok SN z dnia 10 października 2019 r., I PK 196/18, OSNP 2020, nr 9, poz. 92.

\section{Strony internetowe}

https://www.gov.pl/web/rozwoj-praca-technologia/szacunek-mrpit-62wyniosla-stopa-bezrobocia-rejestrowanego-w-grudniu-2020-r

\section{Licenciement pour des raisons non liées à la pandémie de COVID-19}

\section{Résumé}

Cet article vise à évaluer la réglementation anti-crise du point de vue du niveau de protection des intérêts des salariés. Les auteurs discutent des questions d'instruments de soutien aux employeurs ainsi que d'instruments du marché du travail dans le contexte de la crise pandémique et des licenciements qui en sont la conséquence. Une attention particulière a été portée à la situation des fonctionnaires de l'administration publique en raison de la spécificité des solutions mises en place par rapport à ce groupe professionnel. Les réflexions sur l'évolution de la pratique des relations de travail collectives et le fonctionnement des parties à la relation de travail ont également été présentées.

Mots-clés : licenciements, COVID-19, raisons non liées à l'employé

\section{Zwolnienia z przyczyn niedotyczących pracowników wobec pandemii COVID-19}

\section{Streszczenie}

Celem niniejszego artykułu jest ocena regulacji antykryzysowych z punktu widzenia poziomu zabezpieczenia interesów pracowników. Autorzy omawiają problematykę instrumentów wsparcia pracodawców, a także instrumentów rynku pracy w kontekście kryzysu pandemicznego i towarzyszących mu zwolnień. Szczególną uwagę poświęcono sytuacji pracowników administracji publicznej ze względu na specyfikę rozwiązań wprowadzonych w stosunku do tej grupy zawodowej. Podzielono się także refleksjami dotyczącymi zmiany praktyki relacji zbiorowych pracy oraz sposobu funkcjonowania stron stosunku pracy.

Słowa kluczowe: zwolnienia, COVID-19, przyczyny niedotyczące pracownika 